\title{
Neoliberalism, Liberal Intergovernmentalism and EU-Turkey Relations
}

\author{
Dimitris Tsaroubas
}

\subsection{INTRODUCTION}

Liberal approaches to regional integration, including neoliberal variants preoccupied with institutional cooperation, have informed scholarship on European integration for a long time. They still do today, and for good reason: their problematization of economic actors and resources offers a welcome departure from the static diplomatic accounts of high level politics, while at the same time allowing for an analysis of the state (and its role in integration) that, occasionally, corresponds more closely to actual policymaking (instead of offering merely a normative account of state behavior). When they first emerged some decades ago, they neatly combined an appreciation for the salience of state interests in allowing for (or inhibiting) intra-state cooperation and combined that with an acute understanding of the important role that markets, technology, and interdependence between firms and states had come to play in contemporary efforts toward regional cooperation. Liberal intergovernmentalism (LI) has managed to achieve the status of a 'baseline theory' on the subject of

\footnotetext{
D. Tsarouhas $(\bowtie)$

Department of International Relations, Bilkent University, Ankara, Turkey e-mail: dimitris@bilkent.edu.tr

(C) The Author(s) 2021

W. Reiners and E. Turhan (eds.), EU-Turkey Relations, https://doi.org/10.1007/978-3-030-70890-0_2
} 
European integration (Schimmelfennig, 2001). In that way, it is a theoretical approach, contested and often doubted as to its explanatory rigor, yet engaged with by most scholars that apply theoretical tools to studying the EU and its policies.

Does neoliberalism, and LI in particular, help us understand the relations between the European Union (EU) and Turkey? The question is far from rhetorical given the significance of this relationship in better understanding and evaluating Europe's regional integration efforts. This chapter begins with a discussion on neoliberalism and its core assumptions before moving on to a more detailed discussion of LI. The next section identifies the key institutions, actors, and policy areas applicable to the relationship between Turkey and the EU with regard to LI from 1963 to the present. The examples chosen, namely the Association Agreement, Customs Union (CU) and accession talks, seek to incorporate case studies that would, at first, appear both to fit well with liberal intergovernmentalist assumptions and those that do so to a lesser extent. In doing so, that section also discusses critiques against liberal approaches to enlargement as well as the specific case of Turkey. The conclusion summarizes the main findings.

Overall, I argue that liberal intergovernmentalist approaches to EUTurkey relations are extremely useful in comprehending the set of dynamics that led to the signing of the EU-Turkey CU as well as the interstate forms of cooperation between the two sides in selected policy areas, not least migration and security. LI's emphasis on interstate bargaining and the salience it accords to economic groups at the domestic level also go some way toward explaining, at least partially, the opening of accession talks with Turkey in 2005. Turkish accession to the Union, given the theory's preoccupation with state-society relations and the asymmetry of preferences in the context of interstate bargaining, is difficult to envisage.

\subsection{Neoliberalism: Core Assumptions AND Departure Points}

Neoliberalism has made important contributions in International Relations (IR) theory, especially regarding the role of institutions in facilitating cooperation. The debate between neorealism and neoliberalism in IR theory illuminated different aspects of neoliberalism and allowed for a structured comparison with (neo)realist thinking. Inspected from up 
close, the two perspectives are not that different from one another (Jervis, 1999). Both focus on the state as the main unit of analysis in IR; both view the state as a utility-maximizer in an anarchic world and the maximization of power as crucial for every state's well-being; finally, both view intra-state cooperation as a difficult task, since anarchy allows for unilateral attempts by states to enhance their position and concentrate more resources. There are, however, important differences as well, and these will be discussed below.

Although neoliberalism does not deny the need for security or indeed military power, it does not see these features of the international environment as necessarily determining state behavior. Neoliberalism prefers to focus on other aspects of international governance such as International Political Economy, environmental protection, and regulatory politics. The rationale behind that choice is linked to neoliberalism's approach toward international cooperation. The latter is not only necessary in an increasingly interdependent world; it is also often unrealized, as states find themselves trapped in their own rationality and prove unable to escape from situations whereby enhancing cooperation would make them better off. To be sure, conflict in the international arena exists. Nonetheless, such conflict is, for neoliberals, avoidable and can be minimized through states' appropriate behavior. A large part of the relevant literature on neoliberalism therefore focuses on the set of conditions that would allow for enhanced cooperation. A realist reading of IR, even when analyzing cooperation, would draw attention to the implicit or explicit distributional conflicts inherent in attempts to spread cooperation: for neoliberals, though such conflicts often occur, they are decidedly less significant than the gains that states can expect to make. It is in that sense that relative gains matter for neoliberals much more than absolute gains.

What are the conditions that facilitate cooperation then, and how can conflict be mitigated? Two of the most important variables underlined by neoliberalism are information asymmetries and transaction costs. States will often fail to cooperate less because of malign intentions and more because they lack knowledge about the other side's intentions. Failure to know, and therefore to understand, can then lead to an uncontrollable spiral of tension, the outcome of which may be open conflict (Mercer, 1996). In that regard, state reputation plays a vital role in signaling one's intentions and reducing the possibility of misunderstandings (Mercer, 1996; see also Reiners \& Turhan, Chapter 16). Importantly, this is not to be confused with reputation, which adds to a state's legitimacy by way 
of a normative 'logic of appropriateness'. Reputation here allows for iterated games to become routine, meaning safe and predictable, allowing rational actors to maximize their benefit. Transaction costs can also be reduced through cooperation.

It is in that context then that neoliberalism underlines the role of institutions in facilitating cooperation, mitigating conflict, and securing a more predictable policy environment. Institutions, for neoliberals, are the 'enduring patterns of shared expectations of behavior that have received some degree of formal assent' (Jervis, 1999: 53). They concur with institutionalists focusing on comparative politics in that they stress how institutional settlements frame the context within which subsequent action often takes place and conditions the ability of states/parties/interest groups to shape their immediate policy environment in accordance with their own preferences (Hall \& Taylor, 1996; Streeck \& Kathleen, 2005). Where exactly lies the value of institutions then? Clearly, institutions have a functional role to play in reducing (sometimes eliminating) transaction costs as well as information asymmetries. Through their presence, they allow states to concentrate on benefit maximization. Yet, the most important aspect of institutions stressed by neoliberals, in sharp contrast to neorealist thinking, is that institutions can acquire a life of their own: that is, they are important in themselves and not merely as instruments of states. To put it in another way, neoliberals claim that the right institutional setup matters not merely in reducing the possibility of conflict but also because institutions themselves can change the calculations made by states, alter their set of preferences, and thus lead to forms of cooperation that may not have been envisaged to start with (Keohane \& Martin, 1995; Russett et al., 1998; Simmons \& Martin, 2002).

It is neoliberalism's institutionalist emphasis that makes it not only different from neorealism but also opens new avenues of thinking about regional integration. Neoliberalism applied to regional integration theory starts from the assumption, sometimes demonstrated in practice, that institutional settlements can transform the set of preferences that decisionmakers are likely to adopt. This process will lead to the formation of more complex networks of interdependence, whereby any subsequent move adopted will be based on a cost-benefit analysis that does not spring from that specific round of exchange or bargaining but one adopted earlier. Over time, this leads to a situation whereby the institutional environment constrains statecraft to a degree unimaginable by neorealists, leading to 
situations that are difficult to reconcile with a more traditional, statecentric understanding of international relations. The evolution of the EU and the pooling of states' sovereignty can thus be explained in this institutionalist manner.

Nevertheless, sovereignty remains a cornerstone of the identity that EU states maintain, and although often pooled and stretched in ways unforeseen, it maintains a supreme role in the EU policymaking setup. Delving deep into regional integration theory and seeking to make a distinct contribution to the puzzle of the EU, LI is worth exploring in some detail.

\subsection{Liberal IntergovernMentaLism:}

\section{A Three-Step Approach to European InTEgration}

If neoliberal institutionalism assigns an autonomous role to institutions, LI offers a different interpretation as to the evolution of the EU and its major decisions over time, more akin to a rational choice institutionalist perspective (Moravcsik \& Schimmelfennig, 2009: 67). It also departs from the neofunctionalist approaches to integration and returns the focus to member states and their decisions. However, it incorporates elements of liberalism in explaining states' decision-making processes and seeks to account for the emergence of supranational EU institutions as well, while firmly grounded on the popular intergovernmentalist approach to regional integration.

To begin with, it is worth quoting the interpretation of EU integration by Andrew Moravcsik, the most prominent LI scholar. Though the definition was written more than twenty years ago, its basic premises still hold; indeed, their durability is what makes LI one of the most frequently cited theoretical approaches to the study of the EU:

EU integration can best be understood as a series of rational choices made by national leaders. These choices correspond to constraints and opportunities stemming from the economic interests of powerful domestic constituents, the relative power of states stemming from asymmetrical interdependence, and the role of institutions in bolstering the credibility of interstate commitments. (Moravcsik, 1998: 18)

Moravcsik's formulation encapsulates the gist of the LI argument and places, in sequential order, the successive steps that the theory applies to 
explaining how and why integration has come about. We examine those below in turn, starting from the formation of national preferences and the role of domestic groups.

\subsubsection{Step One: State-Society Relations and the Formation of National Preferences}

From a liberal point of view, states' foreign policies are formulated as a result of the governments' interactions with domestic social groups. Therefore, state preferences cannot be assumed to be a priori fixed; they tend to evolve in accordance with the way in which domestic groups pressure their governments and as the latter seek to respond to those pressures (Moravcsik, 1993). This flexibility in the interpretation of state preferences allows LI to account for a variety of different policy positions among EU member states and underlines the salience of institutions in domestic settings, whether political, social, or economic. What kind of positions are states expected to assume based on an LI reading of integration? This is also impossible to presume without examining the specific policy area of major concern to a given state.

Although LI is often said to privilege economic issues over political ones, and especially producer groups' interests, this does not always have to be the case. LI pays special attention to interdependence and the forces of globalization, yet it underlines that there may well be policy areas (for instance immigration policy) where economic interest groups will not dominate the calculations of policymakers in formulating their state's policy position (Wincott, 1995). As will be shown below, this is particularly relevant with regard to EU-Turkey relations today and the central role assumed by the two sides' agreement on managing migration flows in 2016.

One of the most important LI insights in this respect is that EU integration began on the basis of concrete, issue-specific economic concerns and, therefore, was for a great period of time (indeed until today) dominated by state preferences formulated on that basis (Moravcsik, 1998: 3). This by no means suggests that factors such as geopolitics or ideology are to be excluded from the analysis: they have to be considered and examined. However, they tend to be of secondary importance in the great moments of deepening integration. The issue at stake, therefore, is less whether politics or economics matter but the relative weight of these variables in explaining state preferences. Moreover, LI's great advantage 
is its flexible nature, being after all a synthesis of commercial liberalism and rational choice institutionalism. In that sense, the theory foresees the possibility of ideological and geopolitical reasoning playing an important role in decision-making processes should economic interests be weak and cause-effect relations uncertain (Moravcsik \& Schimmelfennig, 2009: $85)$.

In line with this approach, EU-Turkey relations have developed over time based on a mutual rational choice calculation. Bilateral relations have varied depending on two major variables: (a) the costs associated with cooperation/non-cooperation that powerful domestic groups would have to bear; and (b) the variable geometry of state preferences at the level of the European Council and the Council (see Turhan \& Wessels, Chapter 8).

\subsubsection{Step Two: Interstate Bargaining}

Once preference formation is complete at the domestic level (if only for a brief period and if only in specific issue areas), how do states come together at EU level? The bargaining process that ensues is by definition hard and prolonged, with different deals agreed between countries whose options and preferences vary. The bargaining outcome therefore reflects (relative) power relations between states as well as the degree of willingness they possess to strike a deal on a specific issue (Moravcsik \& Schimmelfennig, 2009: 71). This affirms that there are important power asymmetries within the EU and that some states may be able to play their bargaining cards better than others. Nevertheless, and that is an important qualification, asymmetry is not necessarily the result of military prowess or economic might: it is often the result of states' relative position to other states with regard to the benefits they expect to derive from a particular bargain. States are, in that sense, asymmetrically dependent on one another and possess knowledge of this asymmetry (Moravcsik, 1998: 8). This can go a long way in explaining their bargaining strategy as they seek to compromise often conflicting preferences and develop a new arrangement (a treaty or major policy initiative) with which they can all live. A further key point is the disproportionately high amount of power that large member states retain in the EU negotiation process, especially at the level of the European Council.

According to the LI approach, major EU treaties have been fought over by states insisting on their own preferences and yet willing to 
compromise when the stakes were high. Why? Because they were aware of the disproportionate benefits they were likely to acquire if they compromised on issues of secondary importance to them (Moravcsik, 1998: 3). Rational and aware of the iterated game-setting in which they have been drawn, states have not hesitated to threaten to veto proposals, or indeed exercise that right, whenever they felt that the cost-benefit calculation they engaged in saw them potentially ending up with less than they had expected to gain. On the opposite side of the spectrum, those states with less to gain at any particular bargaining round could afford to behave in a more obstructionist manner and press for more concessions, aware that their own loss in case of a collapse of bargaining was likely to be minimal.

A question that arises relates to the salience of institutions and the role of supranational institutions. LI concentrates on the role and bargaining power of member states; leaving little room for supranational actors to contribute to the formation of state positions in the context of momentous decisions, such as treaty revisions. There are exceptions to be sure, as Moravcsik (1998: 12) recognizes with regard to the signing of the Single European Act in 1986, in which the European Commission (EC) and then President Jacques Delors, in particular, played an active role. However, and this is key in understanding the rationale behind LI approaches, information asymmetries and transaction costs are not thought to be excessive within the EU policy- and decision-making structure. States know more or less what others think as well as what they know; they hardly feel the need to employ bodies such as the EC to cover those gaps, let alone allow such bodies a disproportionately high degree of decision-making autonomy. Supranational institutions are here facilitators for state preferences, sharply distinguishing LI from the more supranationalism-friendly interpretations of neofunctionalist theory. From an LI point of view, EU-Turkey relations are subject to hard intergovernmental bargaining premised on member states' willingness to achieve desired outcomes as well as an outcome acceptable to all. Offering Turkey candidate country status in the 1999 Helsinki Summit is instructive. Following turbulence in the Balkans and with the Kosovo war ongoing, the Union's decision to offer Turkey the prospect of EU membership was linked to the unanimous EU desire to maintain stability in a volatile region. The role played by individual member states mattered, too, however in that they saw stronger relations between the EU and Turkey as an opportunity to maximize their own benefits. Greece pressed and succeeded to have its bilateral disputes with Turkey upgraded to the 
European Council level prior to the Helsinki Summit. Because of pressure from Greece, Cypriot membership to the EU would go ahead even without a solution to the Cyprus problem, while all candidate countries would have to recognize the jurisdiction of the International Court of Justice in resolving bilateral disputes (Terzi, 2005).

\subsubsection{Step Three: Institutional Formation}

The LI model conceives of a third step in integration explaining why institutions come to be formed. In the history of integration, multiple new institutions have been formed, many of them able to acquire more power over time. Beyond the obvious example of the EC, it is worth highlighting the role played by the European Central Bank in alleviating the immediate consequences of the financial and economic crisis.

In explaining the role of institutions, LI borrows heavily from regime theory (Keohane \& Nye, 1977), which views institutions as essential ensuring that unwanted consequences in uncertain conditions will be effectively mitigated. In that sense, institutions play a crucial role in reducing the uncertainty that states face in a collective context and are necessary to ensure the durability of agreements reached and their effective implementation over time. This is not to be equated, however, with member states' permission to institutions to do as they see fit once established. When supranational institutions do gain more Treatybased powers, this is the result of an attempt to control and cajole others in complying with commitments made earlier and to allow for the possibility of imposing sanctions in case of non-compliance. The noncompliance problem is common in international organizations, and LI attempts to explain the emergence of such institutions through a rational institutionalist approach (Pollack, 2003). Finally, LI asserts that supranational institutions tend to be reduced to the role ascribed to them in the EU. The vast majority of EU policy implementation, including abiding by regulatory standards, remains the responsibility of national administrations.

With regard to EU-Turkey relations, the role of the EC comes into sharp focus. Not least through its annual progress reports published since 1998, the Commission has been tasked by the Council to monitor Turkey's progress toward accession and warn the Council of possible red flags. Worsening progress reports after 2007-2008 played a role in reducing the pace of EU-Turkey negotiations and ultimately bringing the 
process to a near stalemate (Macdonald, 2018). However, LI foresees that the ultimate decision on negotiations rests with member states. To illustrate, the EU-Turkey refugee 'deal' reached in March 2016 has little to do with supranational institutions and all to do with the alignment of interests between major political actors, most notably Chancellor Angela Merkel of Germany and President Recep Tayyip Erdoğan of Turkey (see also Reiners \& Tekin, 2020). Further, although institutions such as the Commission and Parliament have played an important role in first encouraging and then discouraging accession talks, Turkish policymakers have emphasized that, to them, the real decisions relating to Turkey's accession lie with EU leaders, that is, the European Council (Erdoğan, 2004). They have underlined the complementary character of supranational institutions, often ignoring the real value that lies with them, either in seeking to reinforce Turkey's EU path in times of mutual distrust (as with the Commission's Positive Agenda initiative in 2012 (European Commission, 2012)) or, voicing their opposition to Turkish accession on grounds of a malfunctioning democracy (as in the case of the EP's vote to freeze accession talks in 2016 (Kroet, 2016).

\subsection{EU-TURKey ReLATIONS Over Time: Testing LI Theory}

\subsubsection{The 1963 Association Agreement}

The relationship between Turkey and the then European Economic Community (EEC) dates back to the 1963 Association Agreement (also known as the Ankara Agreement) between the two sides. Turkey applied for associate membership in 1959, and the Agreement signed in Ankara four years later sent the two sides' relations down an institutionalized path that remains in place. The primary aim of the agreement was to boost economic ties between the two sides and assist Turkey's economic development through financial assistance and higher trade volumes. At the same time, the agreement foresaw a three-stage negotiation process through which a CU with Turkey became the core objective. This became reality by 1995 , much later than originally envisaged.

Why was the Association Agreement signed? For Turkey, Germany was one of its major trading partners in the postwar era (along with the United States) on important products such as tobacco. Economic 
arguments stood side by side with Ankara's attempt to enhance its international status and align itself with the nascent Community in the context of the Cold War rivalry and Ankara's Western-oriented foreign policy. Moreover, Turkey applied for associate membership only a few months after Greece did in an attempt not to be left behind. Germany stood to benefit from a $\mathrm{CU}$ with one of its major trade partners and so did other EEC countries, such as the Benelux states, whose export-oriented model also stood to gain from closer economic ties with Turkey. Countries such as France and Italy, on the other hand, saw in Turkey a direct rival for many of their agricultural products and resisted the idea of a $\mathrm{CU}$, pushing this further down the road. For France then, as today, Turkey's European identity was questionable, which proved an obstacle for Turkey in negotiations (Erdoğdu, 2002). German willingness to reach an agreement prevailed after such a concession was made, but only after incorporating Article 12 into the agreement and allowing for the transfer of Turkish migrant workers to Germany to supply the German labor market with much-needed workers during the postwar labor shortage. This agreement facilitated full employment and the emergence of the German Wirtschaftswunder, the 'economic miracle' of the postwar years (Capoulongo, 2015: 7-9). Bargaining between the two sides led to a three-phase agreement, the last stage of which envisaged the possibility of Turkey's EU membership, but only after Turkey abided by Treaty obligations and without offering any concrete timetable to that effect.

All in all, domestic interest groups and their salience are less important than interstate bargaining and a process of state preference formation, by both the EEC and Turkey, in explaining the signing of the Association Agreement. Tangible economic and political benefits, and the willingness of Germany to reach an agreement on an issue of high salience to its domestic policy agenda, played a key role.

\subsubsection{Turkey's Membership Application and the Signing of the Customs Union}

In 1987, Turkish Prime Minister Turgut Özal spearheaded Turkey’s EU candidacy, and the country officially applied to join the bloc. A lot of water had flowed under the bridge since 1963: EU enlargement had taken place and the Union now numbered 12 members, Turkey's chronic political instability had led to a three-year-long military regime in the early 1980s, and Turkey's economic model was being transformed away from 
import substitution and toward a liberalized, export-oriented approach to growth. The latter was of special significance for major EU exporters, seeing in Turkey a rising market economy with large growth potential, but is not the only salient factor here. The rise of political Islam in Turkey had been underway for some time already in 1987, and Turkey's political elite, as well as its secular business elite based in Istanbul and other major western cities, was fearful of a possible drift away from Western values. Özal and most of his successors during the 1990s used this political argument to obtain EU concessions, anchor their country to the Union, and complete the CU process (Ulusoy, 2007: 484).

The EEC was caught by surprise by Turkey's application: not least due to divisions among them and in order to partially externalize decisionmaking costs, member states asked the Commission for an opinion on the matter, and it took more than two years for the opinion to be released (European Commission, 1989). The negative assessment of Turkey's application cited socio-economic factors: structural disparities regarding agriculture and industry, low social protection as well as more technical arguments concerning the need to prioritize the completion of the Single Market over enlargement (European Commission, 1989). Moreover, the Commission also referred to democratic deficiencies in Turkey regarding freedom of expression or the right of minorities. By the 1980s, the Community had been transformed following the accession of former dictatorships in Greece, Spain, and Portugal: political criteria such as democracy and human rights would from now on become part and parcel of EU conditionality, a development that Turkey would confront time and again, not least following the adoption of the Copenhagen criteria in 1993 (Kahraman, 2000). The fact, however, that the same Commission opinion stressed the need for 'intensifying relations' between the two sides underscores the calculation in Brussels and most member states: Turkey remained too important, both economically and politically, to be ostracized. Member states were able to neither support nor reject Turkey's application as a result of the Commission opinion: Greece was alone in objecting to possible Turkish membership (Y1lmaz, 2008: 5). To sweeten the bitter pill, the Council tasked the Commission to develop a plan to keep relations with Turkey on track, and the Commission set out a working program in 1992 aimed at completing Turkey's membership into the CU (Arikan, 2006).

While uncertain and divided on the question of Turkey's membership, member states undoubtedly wished to keep Turkey in the Community 
fold. The implementation of the CU, foreseen in the Ankara Agreement, had not taken place at this time, but by the mid-1990s conditions had become ripe. The EU stood to gain from anchoring Turkey in its markets and requested that Ankara expose itself to international competition. For Turkey, membership in the CU was seen (or interpreted) as a decisive step toward full EU membership. Greece, which had traditionally used its veto-wielding powers against Turkey's closer ties with the EU, now dropped its objections after receiving assurances that negotiations with Cyprus for membership would soon begin (Vidal-Folch, 1995). This exchange was, for Greek policymakers, an outcome that maximized their leverage. Because of the lifting of the Greek veto in the mid-1990s, the EU-Turkey CU came into being. Turkey's industrialists initially viewed the effects of the $\mathrm{CU}$ with suspicion, fearful of enhanced competition (Eralp \& Torun, 2015: 17). Over time, however, the benefits from it have outweighed the costs (Togan, 2015).

Regarding the CU, one sees a successful case for LI and neoliberalism more generally, through which economic gains are spread to participating states and the institutions formed thereafter secure safe returns for contracted parties. A trickier case, however, is the start of accession negotiations with Turkey in 2005 , to which we turn next.

\subsubsection{Turkey's EU Accession Talks: A Difficult Case}

Things get more complicated when the focus shifts to politics, and in particular when ideational perspectives enter the fray (Schimmelfennig, 2001). After all, explaining the decision to open accession negotiations with Turkey in 2005, and therefore opening the way for its full incorporation to the EU, is difficult to reconcile with an approach that sees domestic groups as key, given strong skepticism among the EU population over Turkish entry (Gerhards \& Silke, 2011). More importantly, many member states stand to lose from Turkey's full entry: competition for scarce EU resources would increase and less prosperous states would have to join cohesion and solidarity funding with a large state more populous but poorer than them. Even if one allows for the LI claim that distributional consequences in the case of enlargement to Central and Eastern Europe were insignificant for EU-15 states, thus allowing for enlargement (Moravcsik \& Vachudova, 2003), the same can hardly be said about Turkey, by far the largest among candidate countries. 
In that context, then, and from an LI perspective, the decision to start accession talks is indeed a puzzle. This is linked to some of the criticism directed toward LI in particular for its neglect of previous commitments made by national governments and the rhetorical entrapment (Schimmelfennig, 2001; see also Schimmelfennig, Chapter 6) they subsequently face when confronted with candidates arguing about the relevance of their candidacy and the 'Europeanness' of their polity.

On the other hand, LI retains some explanatory power here, as well. Powerful domestic groups in key member states, such as the Federation of German Industries (BDI), openly backed Ankara's accession bid. What is more, the BDI has been vocal in its support for continued accession talks with Turkey as late as in 2013: that is, when relations had started to sour (BDI, 2013). Stressing the salience of Turkey's geostrategic importance and the fact that Germany is the country's biggest trading partner were foremost in the BDI's argumentation. Further, leading politicians in EU states were keen to emphasize the potential security gains for the Union with Turkey in it. In such an event, the argument went, the EU would demonstrate its openness to Islam and the Muslim world (Desai, 2005).

In that sense, LI's emphasis on the prioritization of economic, sectorspecific interests and its focus on asymmetrical bargaining at the level of the European Council and the Council appear vindicated. Moreover, the decision to begin accession negotiations was formulated in such a way that the open-ended nature of the negotiations' outcome allowed for member states to read into the agreement whatever they wished. After accession talks had been agreed, French President Jacques Chirac stated that the issue would eventually be put to a referendum, a view echoed by Austrian Chancellor Wolfgang Schüssel (Yilmaz, 2008: 11).

\subsubsection{The EU-Turkey Trajectory Post-2005: Transactionalism in Action}

LI stresses the dominance of national predilections, the complexity of bargaining between states with asymmetrical preferences on Turkey, and the prioritization of economic and issue-specific interests over the more comprehensive and complex political relations that EU accession entails. It also maintains a rather skeptical view regarding enlargement in general, as new member states make bargaining ever more complex, thus making it harder to find a common denominator satisfying diverse priorities. 
The start of accession negotiations in 2005 was controversial among many EU capitals and thus included several provisos that impeded progress in Turkey's accession talks. To start with, no EU acquis chapter was to be fully closed unless all of them had been successfully concluded. Second, although the aim of talks was full accession, other forms of aligning Turkey to the EU remained open in case accession talks stalled. Third, some member states reserved the right to ask their people via a referendum as to whether they would approve Turkish membership once negotiations had been concluded (BBC, 2004). No previous enlargement round had been negotiated under such circumstances, and the fact that Turkey-skeptic governments had taken over in France and Germany played into the hands of forces wishing to stall Turkey's accession progress. Moreover, the credibility of conditionality was compromised early when senior political figures disputed Turkey's 'Europeanness', thus deeming it ineligible for full membership (Uğur, 2010: 967-992), while rising Euroskepticism made things worse. Turkey's reform momentum, which had kicked off following the 1999 Helsinki Summit and culminated in political and economic progress by 2005 , stalled afterwards. Ankara's erstwhile enthusiasm gave way to increasing skepticism and accusations of 'double standards' against Brussels, and major EU capitals became subject to Turkey's EU bashing (Hale, 2012). Progressive reforms were gradually rolled back (Aybars et al., 2018), despite the Commission's attempts to keep the talks going through initiatives such as the 2012 Positive Agenda (European Commission, 2012). The EU anchor soon lost its relevance in Turkey's domestic political debate, yet foreign direct investment (FDI), mostly originating from EU states, continued to flow into the Turkish economy. An increasing disjunction between political and economic relations ensued. The attempted coup in the summer of 2016 and the subsequent crackdown by Turkish authorities only made the situation worse. In 2020, the prospect of Turkey joining the EU is as distant as it was more than 20 years ago.

The EU-Turkey trajectory since 2005 fits a liberal intergovernmentalist approach. Member states remain divided on the question of Turkish accession, with some, such as Sweden and Spain, forming a small 'Friends of Turkey' circle, and with others, such as Austria, Cyprus, and France, remaining intensely skeptical. This diversity of preferences makes a decision difficult to reach. Hence, the concept of a 'privileged partnership' as first molded by Germany's Christian Democrats (Euractiv, 2004) (and other major industrial member states) is greatly beneficial to the EU 
as it keeps Turkey economically anchored to the EU trade and industrial market structure through the $\mathrm{CU}$ while Turkey is prohibited from striking its own agreements with countries bound by agreements struck with the EU. FDI flows from Europe to Turkey make the latter dependent on such flows and increase the leverage of member states over Turkish decision-makers. The latter have often threatened Europe with the end of negotiations but have yet to take that step. According to LI, they are very unlikely to do so in the future, unless Turkey's economic salience becomes fully overshadowed by chronic political instability and isolation from the West.

Full Turkish membership would make the country an equal partner both politically and economically, raising its clout and redirecting resources away from current recipients. Instead of full membership, therefore, the EU aims at anchoring Turkey to its structures, since the country remains a major market for its goods and a vital regional player in a volatile region. Turkey wants EU accession much more than the EU does (or at least used to), and this bargaining asymmetry allows the Union to impose a de facto differentiated form of integration with Turkey, cooperating closely with it when it stands to benefit from such cooperation and rejecting full membership due to the strains it will impose on it.

The refugee crisis provides further testimony to that argument: the set of preferences for member states was clearly tilted in favor of outsourcing the problem of incoming irregular migrants and refugees, as the issue reached an explosive nature and threatened to destabilize domestic EU polities and integration itself. Turkey was a convenient partner for outsourcing, and the deal reached between the two sides relieved EU member states, primarily Germany, from a major problem. Using its classical tools of financial assistance and providing promises on accession talks and visa liberalization, the EU was able to entice Turkey to sign the deal. However, accession talks have been and remain part of democratic conditionality: Turkey's backsliding in this regard has allowed for the implementation of the deal without Ankara taking any concrete steps toward accession. From an LI perspective, a form of association between the EU and Turkey makes full sense, allowing the Union to benefit from the (economic and trade-related) leverage it holds over the country and use its relations with Ankara to deal with issue-specific problems, such as migration. Finally, confirming the centrality of member states and their preferences in decision-making is the fact that the EU-Turkey refugee 'deal' was made possible once the European Council opted for it (see 
Turhan \& Wessels, Chapter 8). The deal, which led to a sharp reduction in the number of irregular arrivals in EU member states (European Commission, 2018) became possible after the EU Heads of State or Government and the Government of Turkey released an 'EU-Turkey Statement' (European Council, 2016) to end irregular migration flows, assist Turkey in managing the flows, and provide for legal pathways for Syrian refugees to reach EU territory.

The EU decision to externalize migration governance to Turkey (Tsarouhas, 2018) became topical again in 2020, when the Turkish government decided to open its border to migrants wishing to leave. Chaotic scenes followed, with thousands of Pakistanis, Afghans, East Africans, and some Syrians trying to cross into Greece. The latter claimed the right to defend itself from an unexpected 'invasion', while Turkey claimed that the EU's lack of solidarity toward Turkey prompted the move (Boffey, 2020). While the Commission president openly accused Turkey of politicizing the border to gain concessions from Brussels, European Council President Charles Michel referred to 'differences of opinion' and called for an open dialogue to overcome the challenge. The Union tasked the High Representative Josep Borrell to work with the Turkish foreign minister and come up with a way of overcoming differences regarding the migration deal. Turkey decided to open the borders to extract more support from Brussels, not only regarding financial assistance within the framework of the existing refugee 'deal' but also political support for its deep military involvement in Syria, which resulted in scores of dead Turkish soldiers. When EU leaders visited Greece and toured the border area together with the Greek prime minister, the solidarity displayed toward Greece indicated the failure of Ankara's move (Fox, 2020).

This latest deterioration in EU-Turkey relations followed rising tension in 2018 and 2019 over the exploitation of hydrocarbons in the Eastern Mediterranean. Turkey conducted drilling off Cypriot territorial waters and with no agreement between the two sides on delineating their respective Exclusive Economic Zone. Despite EU warnings Turkey went ahead with a second drilling operation and a series of sanctions followed. In July 2019 the Council decided to freeze Association Council talks with Turkey, suspend all high level dialogue meetings between the two sides, and reduce pre-accession financial assistance for 2020 (Council of the European Union, 2019a). In November and amidst continued drilling by Turkey, the Council imposed an EU travel ban and asset freeze on Turkish individuals behind the 'unauthorised drilling activities of hydrocarbons in 
the Eastern Mediterranean' (Council of the European Union, 2019b). Sanctions and measures followed the call by the European Parliament in March 2019 to fully suspend EU accession talks with Turkey (European Parliament, 2019).

The assumptions and projections of LI in the post-2005 are confirmed. Enlargement to Turkey is a very distant prospect and asymmetrical preferences on Turkey make accession unrealistic. Brexit has weakened the 'Friends of Turkey' circle considerably, as have Ankara's actions in the Middle East and the Eastern Mediterranean. Divisions within the Council on Turkey remain but are currently overshadowed by Ankara's belligerent and rather dismissive approach to the Union. If relations improve, these divisions will emerge again. Powerful economic ties make cooperation relevant and even necessary, if only on a pragmatic and transactional basis. The migration crisis is a clear example: although tensions rose again in 2020, both sides maintain open channels of communication. Turkish President Erdoğan was invited to Brussels for talks with the Council and the Commission, and a few days later a meeting involving the leaders of Turkey, Germany, France and the UK took place on the migration deal and the situation in Syria (Euractiv, 2020). Relations with Turkey are now handled at a strictly intergovernmental level involving the heads of state and government, as the latest Merkel-Erdoğan-Macron meeting reveals. The Commission's role is secondary, as the Positive Agenda reveals, and the voice of the European Parliament, while loud, is hardly affecting the day-to-day handling of relations with Turkey.

\subsection{ConClusion}

This chapter has examined the core assumptions and departure points of neoliberalism and LI in IR. Neoliberalism's emphasis on the centrality of states in mitigating conflict and the institutionalist focus on regular interaction that builds trust and is even able to alter state preferences sits well with the evolution and development of the EU. LI, directly applicable to regional integration theories, shares most of the neoliberal institutionalist assumptions and adds layers of complexity through its three-step model of explaining the emergence of the EU as well as its major decisions over time.

LI is a major EU integration theory but has clear explanatory limits. Its rationalism struggles to account for the ideational and normative 
elements embedded in at least some of the Union's policymaking, especially regarding external relations and enlargement to poorer states. Its emphasis on state-society relations as the initial integration step appears unrelated to the elite-driven origins of Cold War-era integration. Its disregard for supranational institutions downplays the role played by individual actors representing supranational institutions such as Delors in launching the Single Market or Draghi in diffusing the Eurozone crisis.

In the case of EU-Turkey relations examined above, and considering the evolution of relations in recent years, LI is a credible and convincing theoretical approach. It successfully accounts for the development of economic ties between the two sides starting from the 1960s, and its analytical tools also justify the continuous ups and downs in bilateral relations over the last decades. A form of association between the Union and Turkey is consistent with the three steps of LI, and one can plausibly argue that such an association is in fact exactly what underpins their relations. The EU and Turkey are joined by a CU (from which both, but especially the EU, benefit), have institutionalized cooperation and common bodies (supervised and directly controlled by states), and enjoy close ties on issue-specific areas, such as migration. The Union is likely to cultivate close ties with Turkey in a differentiated manner and to the extent that the specific policy area under consideration is one in which member states have clear and intense preferences. The trajectory that accession negotiations have followed since 2005 points to the new emphasis, by both Turkey and the EU, on issue-specific cooperation and the salience of member state preferences as well as powerful economic groups in a few member states.

\section{REFERENCES}

Arkan, H. (2006). Turkey and the EU: An awkward candidate for membership. Aldershot: Ashgate.

Aybars, A. I., Copeland, P., \& Tsarouhas, D. (2018). Europeanization without substance? EU-Turkey relations and gender equality in employment. Comparative European Politics, 17(5), 778-796.

BBC. (2004, December 17). Deal struck over Turkey-EU talks. http://news. bbc.co.uk/2/hi/europe/4103931.stm. Accessed 19 Nov 2020.

Boffey, D. (2020). EU and Turkey hold 'frank' talks over border opening for refugees. https://www.theguardian.com/world/2020/mar/09/turkeyerdogan-holds-talks-with-eu-leaders-over-border-opening. Accessed 3 June 2020 . 
Bundesverband der Deutschen Industrie (BDI). (2013, February 25). BDI-Präsident Ulrich Grillo: Industrie befürwortet Fortsetzung von Beitrittsverhandlungen. Berlin. https://www.presseportal.de/pm/6570/242 2339. Accessed 22 Nov 2020.

Capoulongo, F. (2015). La Turquie fait partie de l'Europe. The Ankara agreement: The path towards, the reasons behind (GOGLOB Working Paper). https://www.sis.unitn.it/alfresco/download/workspace/SpacesStore/0af 18f10-d2ef-458b-a7e6-32a856ceef36/02\%20jmcapoluongo.pdf. Accessed 27 Nov 2020.

Council of the European Union. (2019a, July 15). 3709th Council Meeting, Foreign Affairs, Outcome of the Council meeting. 11260/19. Brussels.

Council of the European Union. (2019b, November 8). Council decision concerning restrictive measures in view of Turkey's unauthorised drilling activities in the Eastern Mediterranean. 13262/19. Brussels.

Desai, S. (2005). Turkey in the European Union: A security perspective-Risk or opportunity? Defence Studies, 5(3), 366-393.

Eralp, A., \& Torun, Z. (2015). Perceptions and Europeanisation in Turkey before the EU candidacy: An overview of history. In A. Tekin \& A. Günay (Eds.), The Europeanization of Turkey (pp. 14-30). London: Routledge.

Erdoğan, R. T. (2004). Why the EU needs Turkey. Insight Turkey, 6(3), 7-15.

Erdoğdu, E. (2002). Turkey and Europe: Undivided but not united. Middle East Review of International Affairs, 6(2), 40-51.

Euractiv. (2004, February 17; updated 2010, January 29). Turkey rejects proposal for 'privileged partnership' with EU. http://www.euractiv.com/sec tion/enlargement/news/turkey-rejects-proposal-for-privileged-partnershipwith-eu/. Accessed 23 May 2020.

Euractiv. (2020, March 18). Erdogan discusses migrant crisis, Syria with Merkel, Macron and Johnson. https://www.euractiv.com/section/global-europe/ news/erdogan-discusses-migrant-crisis-syria-with-macron-merkel-and-joh nson/. Accessed 3 Jun 2020.

European Commission. (1989, December 20). Commission opinion on Turkey's request for accession to the community. SEC(89) 2290 final. Brussels.

European Commission. (2012, May 17). Positive EU-Turkey agenda launched in Ankara. MEMO/12/359. Brussels.

European Commission. (2018). EU-Turkey statement two years on. https:// ec.europa.eu/home-affairs/sites/homeaffairs/files/what-we-do/policies/ european-agenda-migration/20180314_eu-turkey-two-years-on_en.pdf. Accessed 20 Nov 2020.

European Council. (2016, March 18). EU-Turkey statement. Press release. https://www.consilium.europa.eu/en/press/press-releases/2016/03/18/ eu-turkey-statement/. Accessed 27 Nov 2020. 
European Parliament. (2019, March 13). Parliament wants to suspend EU accession negotiations with Turkey. Press release. 20190307IPR30746.

Fox, T. (2020, March 2). Erdogan's empty threats. Foreign Policy. https://for eignpolicy.com/2020/03/02/turkey-opens-borders-to-migrants-crossing-togreece/. Accessed 3 Jun 2020.

Gerhards, J., \& Silke, H. (2011). Why not Turkey? Attitudes towards Turkish membership in the EU among citizens in 27 European countries. Journal of Common Market Studies, 49(4), 741-766.

Hale, W. (2012). Turkish foreign policy since 1774 (3rd ed.). London: Routledge.

Hall, P. A., \& Taylor, R. C. R. (1996). Political science and the three new institutionalisms. Political Studies, 44(5), 936-957.

Jervis, R. (1999). Realism, neoliberalism, and cooperation: Understanding the debate. International Security, 24(1), 42-63.

Kahraman, S. (2000). Rethinking Turkey-European Union relations in the light of enlargement. Turkish Studies, 1(1), 1-20.

Keohane, R. O., \& Nye, J. S. (1977). Power and interdependence: World politics in transition. Boston: Little, Brown.

Keohane, R. O., \& Martin, L. L. (1995). The promise of institutionalist theory. International Security, 20(1), 39-51.

Kroet, C. (2016). European Parliament votes to suspend Turkey's EU accession talks. https://www.politico.eu/article/european-parliament-votes-to-sus pend-turkeys-accession-talks/. Accessed 3 Jun 2020.

Macdonald, A. (2018). Turkey taking 'huge strides' away from European Union. Reuters. https://www.reuters.com/article/us-eu-turkey/turkey-tak ing-huge-strides-away-from-european-union-top-eu-official-idUSKBNIH O22G. Accessed 3 Jun 2020.

Mercer, J. (1996). Reputation and international politics (1st ed.). Ithaca: Cornell University Press.

Moravcsik, A. (1993). Preferences and power in the European Community: A liberal intergovernmentalist approach. Journal of Common Market Studies, $31(4), 473-524$.

Moravcsik, A. (1998). The choice for Europe: Social purpose and state power from Messina to Maastricht. Ithaca: Cornell University Press.

Moravcsik, A., \& Schimmelfennig, F. (2009). Liberal intergovernmentalism. In A. Wiener \& T. Diez (Eds.), European integration theory (pp. 67-87). Oxford: Oxford University Press.

Moravcsik, A., \& Vachudova, M. A. (2003). National interests, state power and EU enlargement. East European Politics and Societies, 17(1), 42-57.

Pollack, M. A. (2003). The engines of European integration: Delegation, agency and agenda setting in the EU. Oxford: Oxford University Press.

Reiners, W., \& Tekin, F. (2020). Taking refuge in leadership? Facilitators and constraints of Germany's influence in EU migration policy and EU-Turkey 
affairs during the refugee crisis (2015-2016). German Politics, 29(1), 115130.

Reiners, W., \& Turhan, E. (2021). Current trends and future prospects for EUTurkey relations: Conditions for a cooperative relationship. Chapter 16, in this volume.

Russett, B., Oneal, J. R., \& Davis, D. R. (1998). The third leg of the kantian tripod for peace: International organizations and militarized disputes, 195085. International Organization, 52(3), 441-467.

Schimmelfennig, F. (2001). The community trap: Liberal norms, rhetorical action, and the eastern enlargement of the European Union. International Organization, 55(1), 47-80.

Schimmelfennig, F. (2021). Rhetorical entrapment in EU-Turkey relations. Chapter 6, in this volume.

Simmons, B. A., \& Martin, L. L. (2002). International organizations and institutions. In W. Carlsnaes, T. Risse, \& B. A. Simmons (Eds.), Handbook of international relations (pp. 192-211). London: Sage.

Streeck, W., \& Kathleen, A. T. (Eds.). (2005). Beyond continuity: Institutional change in advanced political economies. Oxford: Oxford University Press.

Terzi, Ö. (2005). Europeanisation of foreign policy and candidate countries: A comparative study of Greek and Turkish cases. Politique Européenne, 17(3), $113-136$.

Togan, S. (2015). The EU-Turkey Customs Union: A model for future EuroMed integration. In R. Ayadi, M. Dabrowski, \& L. De Wulf (Eds.), Economic and social development of the Southern and Eastern Mediterranean countries (pp. 37-48). New York: Springer.

Tsarouhas, D. (2018). Turkey and the European migration crisis: Apprehensive cooperation. In A. Prodromidou \& P. Gkasis (Eds.), Along the Balkan route: The impact of the post-2014 'migrant crisis' on the EU's south east periphery (pp. 28-42). Berlin: Konrad Adenauer Stiftung.

Turhan, E., \& Wessels, W. (2021). The European Council as a key driver of EU-Turkey relations: Central functions, internal dynamics and evolving preferences. Chapter 8 , in this volume.

Uğur, M. (2010). Open-ended membership prospect and commitment credibility: Explaining the deadlock in EU-Turkey accession negotiations. Journal of Common Market Studies, 48(4), 967-992.

Ulusoy, K. (2007). Turkey's reform effort reconsidered, 1987-2004. Democratization, 14(3), 472-490.

Vidal-Folch, X. (1995, March 4). Grecia levanta su veto a la unión aduanera entre Turquía y la UE. El Pais.

Wincott, D. (1995). Institutional interaction and European integration: Towards an everyday critique of liberal intergovernmentalism. Journal of Common Market Studies, 33(4), 597-609. 
Yllmaz, B. (2008). The relations of Turkey with the European Union: Candidate forever? (CES Working Paper Series, 167).

Dimitris Tsarouhas is associate professor at the Department of International Relations, Bilkent University, adjunct professor at George Washington University and a visiting researcher at the BMW Center for German and European Studies, Georgetown University. A former department chair (2013-2016) and Jean Monnet Chair in EU Politics, Tsarouhas is a Scientific Council member of the Foundation for European Progressive Studies (FEPS) in Brussels. His research on EU-Turkey relations, Comparative European Politics, public policy and political economy has been published in journals such as Regulation o Governance, New Political Economy, Public Administration, Comparative European Politics, Social Politics, Social Policy \& Administration, Political Studies Review etc. His latest book, co-edited with Owen Parker (University of Sheffield) is entitled Crisis in the Eurozone Periphery: The Political Economies of Greece, Spain, Portugal and Ireland (London: Palgrave, 2018).

Open Access This chapter is licensed under the terms of the Creative Commons Attribution 4.0 International License (http://creativecommons.org/licenses/ by $/ 4.0 /)$, which permits use, sharing, adaptation, distribution and reproduction in any medium or format, as long as you give appropriate credit to the original author(s) and the source, provide a link to the Creative Commons license and indicate if changes were made.

The images or other third party material in this chapter are included in the chapter's Creative Commons license, unless indicated otherwise in a credit line to the material. If material is not included in the chapter's Creative Commons license and your intended use is not permitted by statutory regulation or exceeds the permitted use, you will need to obtain permission directly from the copyright holder.

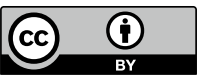

